\title{
A FESTA E A MÁQUINA MITOLÓGICA
}

Furio Jesi

1. Os estudos sobre a festa circunscrevem um âmbito de pesquisas documentais e metodológicas dentro do qual a antropologia cultural, a etnologia, a história (ou ciência) das religiões e as do folclore se submetem, hoje, a uma prova em especial reveladora. As festas dos "selvagens" e as festas do calendário folclórico foram, nos séculos passados, um dos principais objetos de estudo dessas disciplinas: talvez o principal momento, na existência das coletividades estudadas por etnólogos e folcloristas, que - junto com o sacrifício - aparece carregado de determinados estilos de vida, seja como patrimônio mitológico, situado não tanto na existência das coletividades, seja antes delas, como seu precedente fundante. À diferença da mitologia, a festa é, ao menos em aparência, diretamente perceptível e documentável pelo estrangeiro. Enquanto a mitologia, reduzida à pura narração mitológica acessível aos estrangeiros, revela-se de pronto afastada do seu ser em ato, a festa, ainda que observada por estrangeiros, parece intacta e conhecível nos seus gestos, no seu espaço, no seu ritmo, nas suas normas. As reservas particularmente graves que foram colocadas pela reflexão metodológica a respeito dessa cognoscibilidade induziram numerosos estudiosos contemporâneos a renunciar, ao menos em parte, a tal reflexão e a privilegiar a mitologia como elemento peculiar de uma cultura, elemento em relação ao qual parece menos arriscado calcular as margens de incognoscibilidade. Desse modo, entre as ciências humanas dos últimos dois séculos e as de hoje, está sendo realizada uma fratura que põe em evidência soluções de continuidade já latentes no decurso do pensamento antropológico em sentido lato (mascaradas pelo modelo ilusório de um progresso científico linear). O que é colocado em crise é precisamente a possibilidade de relação cognoscitiva entre o observador moderno e a atua-

La festa e la macchina mitologica.

In: Materiali Mitologici. Mito e antropologia nella cultura mitteleuropea.

Org. Andrea Cavalletti. Torino: Einaudi, 2001, p. 81-120.

Tradução de Vinícius Nicastro Honesko. 
lidade de um momento de existência das culturas de interesse etnológico ou folclórico. Por isso, acreditamos que os estudos sobre a festa representam um banco de provas singularmente árduo e revelador. Disciplinas que, até ontem, afrontaram a existência dos "diferentes" e, como seu instante saliente, a festa, encontram-se hoje hesitantes diante de cada aproximação de tal existência em ato. Elas todavia são obrigadas a tomar posição, de algum modo, também diante do problema que tende a resolvê-las em ciência do não-conhecer, e, de tal tomada de posição, é lícito extrair conclusões reveladoras sobre o limite e sobre as possibilidades das ciências do homem.

A aproximação de cada observador ou pesquisador do mecanismo em questão pode ser descrita como a gênese de um determinado modelo gnosiológico, isto é, do esquema determinado sobre o qual, de quando em quando, atuou a experiência cognoscitiva. Cada modelo gnosiológico coincide com um conhecer em ato enquanto durar sua fase genética. Uma vez concluída tal fase, definindo-se completamente o modelo, é mais exato falar de conhecimento reflexo, isto é, do halo de sobrevivência que subsiste em torno ao próprio modelo, então já esquema enrijecido, fórmula dada mais do que conhecer in fieri ${ }^{1}$. Cada conhecer in fieri, cada aproximação não reflexa do mecanismo observado, cada modelo gnosiológico na sua fase genética, é caracterizado e delimitado pela interação entre o quanto há de permeável no mecanismo e o quanto há de permeável no observador: conhecimento, nessa acepção, é encontro de duas permeabilidades, uma e outra condicionadas pelas circunstâncias históricas em que o conhecer é in fieri pelas características que, em tais circunstâncias, são peculiares dos dois entes envolvidos no processo gnosiológico, o conhecedor e o conhecido. Do momento em que o modelo gnosiológico adquire forma estável em definitivo, a permeabilidade do ente cognoscente se reduz ulteriormente; a aproximação do mecanismo por conhecer é, com efeito, condicionado por um fator ulterior: o próprio modelo, que já é uma fórmula dada e que, por períodos de duração variáveis, continua a imporse em certa medida sobre as operações cognoscitivas de quem não participou da sua gênese.

Cada modelo consentiu uma determinada forma de conhecimento (ou, no limite, de não-conhecimento). Examinar todos os modelos juntos, desde o ponto de vista da história das pesquisas e da epistemologia, significa tentar

\footnotetext{
${ }^{1}$ Em latim, no original. Tradução: "em desenvolvimento". (n. t.)
} 
não apenas verificar as características condicionantes das culturas individuais dentro das quais foram formulados e o condicionamento ulterior que eles mesmos exercitaram, depois de ter terminada sua fase genética, mas também uma ulterior forma de conhecimento do mecanismo que eles de vários modos afrontaram e uma reflexão sobre um dos principais problemas de método no âmbito das ciências humanas. Quem recolhe uma série de modelos da festa formulados a partir do século XVI propõe-se a dois objetivos inter-relacionados: o estudo dos condicionamentos primários e secundários que intervêm na gênese dos modelos e no seu influxo ulterior, e uma nova aproximação do fenômeno da festa. Dos modelos precedentes, é possível usufruir de elementos de patrimônio gnosiológico que devem ser colocados em condição de reagir uns com outros, como partes de uma composição na qual consiste o ulterior conhecer. Se cada modelo possui uma objetiva veridicidade gnosiológica, é preciso tentar colocar em funcionamento conjunto os múltiplos modelos, não neles procurando as concordâncias que, mesmo quando existem, permanecem escassamente relevantes por conta da autonomia intrínseca de cada modelo, mas fazendo interagir os diversos modelos e seus coletores. É essa a ulterior aproximação do mecanismo da festa: coadunar e ordenar em uma composição modelos gnosiológicos, de modo que tal composição seja um conhecer in fieri. Mas para atingir tal fim é indispensável tornar as várias partes da composição — os vários modelos - interagentes umas com as outras, não enrijecidas dentro de seus confins individuais, não reparadas, graças à sua definição, pela interação recíproca.

Tornar os modelos individuais gnosiológicos interagentes entre si significa conduzir cada um deles às modalidades de não-conhecimento que são a forma côncava da sua objetividade. Cada um desses modelos é uma criação conceitual autônoma, obediente às próprias leis intrínsecas, justamente por corresponder a determinadas e autônomas modalidades de não-conhecimento. Tornar os modelos interagentes entre si significa tornar atual sua objetividade, portanto, seu aderir a formas individuais de não-conhecimento. A técnica de conhecimento à qual pretendemos recorrer age na tensão entre a qualidade negativa do seu operar cada modelo gnosiológico, em função das modalidades de não-conhecimento que Ihes são próprias, e a qualidade positiva do seu criar por composição. Ela, além disso, deve afrontar o problema da atualidade do seu êxito. Essa atualidade está, por sua vez, em tensão dialética em relação à inatualidade dos elementos da composição, isto é, dos modelos gnosiológicos. 
Se configuramos a vida de cada um destes em termos temporais, observamos que o modelo da sua existência mais difícil de conhecer é o da sua atualidade, do seu "hoje". O seu "ontem", representado pelos fatores que intervêm na sua gênese, pode ser conhecido com relativa facilidade, uma vez que essas mesmas ciências, em cujo âmbito eles são "modelos", dispõem de múltiplos passepartout metodológicos para configurar as origens de um fato com rigor que poderá variar no ato prático, mas que em teoria coincide com o rigor do princípio de causalidade. Esses modelos têm também um "amanhã"; além da sua precisa atualidade, são projetos criativos até o limite da utopia, e, também até a tal limite, os passe-partout metodológicos não separam seu rigor daquele do princípio de causalidade para configurá-los. Quando muito, tratar-se-á, em alguns casos, de passe-partout metodológicos - de modelos gnosiológicos reflexos - suficientemente elásticos para subsistir também onde radicalizam a tensão do conhecer até a suspensão de juízo sobre cada um dos anéis da cadeia de causas e efeitos. Usamos a expressão "modelos gnosiológicos reflexos" pois se trata de passe-partout metodológicos que de fato desenvolvem sua função enquanto refletem os modelos de conhecer ou a eles se adequam por transparência. Nos casos em que refletem o objeto como um espelho maculado, eles nada mais fazem do que se adequar às zonas de escuro que já subsistiam na visão do "amanhã" própria dos criadores do objeto (dos criadores do modelo de conhecer). O "amanhã" de todo modelo gnosiológico, compreendido como projeto criativo, é pleno dessas marcas obscuras além das quais deveriam se esconder os anéis da cadeia de causas; refletir tais obscuridades não é nada mais do que adequar-se às características do objeto por conhecer.

$\mathrm{Na}$ existência do modelo de conhecer, os vários pontos obscuros, isto é, os pontos em relação aos quais nosso conhecimento está em dificuldade sem justificações de adequação fenomenológica, coincidem com os momentos de atualidade: com os momentos do "hoje". O que mais nos foge é precisamente o instante da atualidade dos modelos gnosiológicos que queremos conhecer: o instante em que não nos é possível recorrer a passe-partout metodológicos fundados no princípio de causalidade, uma vez que no "hoje" absoluto, no exclusivamente presente, permanece suspensa a conexão temporal implícita em uma relação de causa e efeito. Se nossa metodologia é de todo condicionada pelo princípio de causalidade, aqui ela se freia, encontrando-se diante do outro por excelência. Considerada de maneira autônoma em face a seu "ontem" e a 
seu "amanhã", a coisa do "hoje" absoluto é inacessível a ciências humanas que não disponham de metodologia autônoma ao princípio de causalidade.

Essas considerações são aqui especialmente oportunas, uma vez que o objeto que serve como denominador comum dos diversos modelos gnosiológicos aos quais nos referimos é um fenômeno - a festa - cujas manifestações chamam a atenção sobretudo para seu "hoje", para sua atualidade que é tão privilegiada a ponto de parecer identificável com sua essência. Nosso trabalho tem aqui o dúplice escopo de verificar, por um lado, as modalidades segundo as quais as ciências humanas de hoje não são capazes de conhecer a festa na sua atualidade; e, por outro lado, de verificar, por meio do estudo das modalidades segundo as quais não somos capazes de conhecer a atualidade dos modelos gnosiológicos aplicáveis à festa, os limites de uma história das pesquisas restritas ao "ontem" e ao "amanhã" dos seus objetos individuais.

No âmbito gnosiológico de tal história das pesquisas, é acrescentada uma ulterior limitação. É verdade que uma pesquisa científica fundada no princípio de causalidade pode obter algum resultado quando indaga seja o "ontem" seja o "amanhã" de um determinado modelo. Mas de pronto fica claro que os resultados da pesquisa sobre o "ontem" são muito mais precários do que aqueles sobre o "amanhã": o "ontem" é, mesmo com amplas margens, definido no tempo, enquanto o "amanhã" não é marcado por um limite post quem. No estudo do "ontem" os objetos tendem a se enrijecer em uma atualidade já acontecida, diante da qual a pesquisa mais uma vez se freia; no estudo do "amanhã", os objetos — os modelos gnosiológicos - permanecem operantes como projetos criativos por tempo indeterminado, e a pesquisa pode proceder na medida em que se identifica com as próprias projeções criativas em ato. Condições objetivas fazem, sim, com que nossa pesquisa se mova solidária ao que sobrevive dos objetos estudados, solidária à sua existência na fase "amanhã", e, assim, ela própria se torna um projeto criativo, ainda que por negação. A antinomia criativa entre criatividade-projeção e negatividade (determinações das modalidades do não conhecer) é, aos nossos olhos, garantia de contribuição para o objetivo epistemológico que nos propomos: a superação por excesso da metodologia em que é estranho o conhecimento do "hoje".

2. "Mas, enfim, quais serão os objetos desses espetáculos? Nada, caso se queira... Plantais no centro de uma praça uma haste com uma guirlanda de flores, reunais o povo e tereis uma festa. Fazeis ainda mais, fazeis dos espectadores um espetáculo: fazeis com que se tornem atores também eles." A noção 
de festa que Rousseau contrapõe às representações teatrais, nesse trecho da Lettre à d'Alembert ${ }^{2}$, revela uma exigência a partir da qual podemos determinar os âmbitos e as modalidades de satisfação, mas não o objeto de satisfação. É uma exigência que deve ser satisfeita de modo eletivo no âmbito gnosiológico e no âmbito político por um fenômeno cuja essência ignoramos, mas para o qual dispomos de um modelo cognoscitivo que desenvolve determinadas funções.

Festa, nas palavras de Rousseau, é um acontecimento conhecível e politicamente desejável que envolve uma coletividade. Conhecê-lo é vantajoso pois significa conhecer um fenômeno humano simultaneamente desde o exterior e desde o interior. A festa envolve uma coletividade, apreende-a como uma mão que a toma e a fecha, e, ao mesmo tempo, acontece em uma coletividade, dentro desta, nascendo com movimento centrífugo que se propaga a partir do ponto da coletividade mais distante das suas bordas externas. Característica da festa, tal como ela resulta segundo tal modelo, é sua prerrogativa de determinar um centro na coletividade: de tornar atual na coletividade o ponto latente mais distante das suas bordas. Nesse sentido, a festa é enraizamento da coletividade no seu íntimo, fundação da coletividade. O que a festa volta periodicamente a fundar não é apenas a estrutura imóvel do cristal da coletividade, evocado pelos paradigmas dos verdadeiros rituais de fundação, mas o dinamismo da coletividade, o movimento orgânico da sua existência. A experiência festiva é ela própria dominada por um movimento que procede das raízes da coletividade, da imobilidade das suas estruturas cristalinas, do destino da coletividade, em direção às horas de escolha - ainda que tal escolha seja com frequência deliberada aceitação do destino -; e esse movimento, que é de propagação, é fatal no seu automatismo como o movimento da respiração, e é totalizante ao ponto de conduzir ao centro todas as partes da coletividade no átimo em que o centro se desvela como tal: "...plantais no centro de uma praça uma haste com uma guirlanda de flores". A experiência festiva não se limita a apreender a coletividade desde o exterior e desde o interior simultaneamente (do exterior da festa que não é ainda e do interior da festa que é, para a coletividade, latência de centro perene), mas, envolvendo

\footnotetext{
${ }^{2}$ Ver também, a propósito desse mesmo trecho de Rousseau, as considerações de STAROBINSKI, Jean. La scoperta della libertà (1700-1789). Trad. Manuela Busino Maschietto. Milano: Fabbri, 1965, p. 85; e de DERRIDA, Jacques. La scrittura e la differenza. Trad. Giovanni Pozzi. Torino: Einaudi, 1971, p. 317.
} 
no centro todas as partes da coletividade, fundando a coletividade, fazendo dela um bloco único no qual o centro permeia de modo uniforme toda parte, coloca o centro da coletividade em contato direto com o exterior dela: identifica o centro com as marcas de confim, faz paradoxalmente do centro a borda externa.

A festa aproxima assim o centro da coletividade, o que ela mais própria e autonomamente é, do seu exterior, o que ela não é. Entre a coletividade e seu exterior permanece uma separação que, antes, é tanto mais nítida quanto mais dela se aproxima o próprio centro da coletividade, seu ser mais peculiar e caracterizante. Mas tal linha de demarcação é penetrável pelos olhares. Em estado festivo é possível ver a coletividade como ela de maneira mais íntima é. Essa permeabilidade gnosiológica da linha de demarcação mostra-se para Rousseau desejável tanto do ponto de vista do puro conhecer - é possível saber o que é uma dada coletividade - quanto do ponto de vista político - é possível estabelecer relações de conhecimento harmônico entre a coletividade, relações a partir das quais procedem harmonias de coexistência que não sacrificam as recíprocas e autônomas peculiaridades, e, até mesmo, realizam sua compenetração. O outro torna-se permeável ao eu pois é possível conhecê-lo melhor; o eu torna-se permeável ao outro pois toca-lhe gnosiologicamente o centro e, portanto, dele sofre o influxo por contato direto. A crise do princípio de identidade, que é traço peculiar da antropologia e da etnologia rousseauniana, radicaliza-se diante da experiência festiva e torna-se a qualidade porosa da superfície que o antropólogo e o etnólogo oferecem à existência e às culturas diferentes. Não por acaso os testemunhos da etnografia recém-inaugurada, em particular no século XVIII, são especialmente ricas de observações sobre as festas dos "selvagens". Além das evidentes razões práticas que exigiam a atenção dos viajantes europeus diante das festas dos diferentes, razões mais claramente ideológicas induziam a caracterizar os diferentes por meio da descrição de suas festas. A operação de auto-alargamento e de auto-justificação do eu, em que podemos configurar o exórdio da etnologia moderna, encontrava as circunstâncias mais apropriadas ao descrever as festas dos diferentes, portanto, ao colocar o eu em relação com o outro quando o outro se revelava centro de si, própria essência, até as bordas do próprio manifestar-se. A consciência teorética dessa oportunidade teria chegado relativamente tarde e, no mais, silenciada como confissão embaraçante de uso interessado da ciência. Tratou-se então de uma oportunidade percebida no 
escuro, e todavia não perdida, já tão necessária a ponto de impor-se obscuramente, por si só, para quem não a procurava conscientemente, mas o que ela custodiava.

3. Permanece todavia enigmático, com efeito, o que era aquilo que oferecia tais vantagens: o que era a festa - a menos que não se queira indicar a essência da festa unicamente no funcionamento útil que lhe é próprio, segundo o modelo descrito. Na fase de reelaboração teorética dos eventos com os quais se abriu a etnologia moderna, a interrogação que se procurou responder é esta: o que é a festa? Mas a exigência que era satisfeita pela festa segundo o modelo rousseauniano dura ainda hoje. Aqueles que, hoje, respondem a tal interrogação, continuam a ser obrigados a preocupar-se muito em definir, em termos científicos, as características disso que serviu e serve para conhecer os diferentes, justamente nos limites de tal função, antes de indagar (uma vez que seja possível) a essência da festa por si mesma, de maneira independente da sua utilidade para estabelecer uma relação com quem se encontra em estado festivo. É possível ter acesso às razões dessa delimitação do problema por meio das palavras com que Károly Kerényi introduz o estudo da "religião antiga como religião da festa" ${ }^{3}$ :

Que a explicação de uma religião parta da fé ou do sentido de realidade: de todo modo, deve ser pressuposto um estado, em que a fé ainda não era fé mas evidência de imediata comoção, com base na qual a ideia religiosa era sentida como realidade; na qual o uso religioso ainda não era uso, mas ato novo, no qual a ideia continuava e se exprimia, talvez de modo tácito, com a exclusividade de um ato emocional.

Tanto o historiador quanto o etnólogo devem confessar que jamais poderão encontrar tal estado de formação in flagranti. Mas a ideia em si é independente do tempo. E onde quer que ela apareça, onde quer que ela seja evocada, traz consigo o elemento de urgência e de comoção que transforma o próprio tempo em momento criativo. Tudo aquilo que momentos similares contêm - seu calor, sua frescura e originalidade - levanta-se, por isso, acima da caducidade do tempo comum. $\mathrm{O}$ etnólogo encontra-se por toda parte em similares momentos transformados - "hohe Zeiten", momentos sublimes -, como a língua alemã os pode chamar com uma bela expressão. Eles são permeados de calor de vida, penetrados por ideias comoventes. Ver-se-á que para eles não falta nem mesmo o elemento criativo. Tais momentos chamam-se festas.

Se há algo a partir do qual possa partir a compreensão da religião antiga e em que a busca filológica e etnológica das religiões possam prestar-se a uma ajuda

\footnotetext{
${ }^{3}$ KERÉNYI, Károly. La religion antica. Trad. Delio Cantimori e Angelo Brelich. Roma: Astrolabio, 1951, p. 45.
} 
mútua é justamente o estudo da essência da festa...

Ao aproximar-se do problema da essência da festa, Kerényi acredita encontrar nela o ponto de contato vivo entre o eu e o outro, ambos colocados dentro do fluir de uma "comoção" além da qual podemos entrever a "comoção" indicada por Frobenius como perene estado criativo da Kultur de um povo. Dentre os estudiosos modernos desses temas, Kerényi se mostrou um dos mais agudos em valorar simultaneamente o aspecto epistemológico do problema e a necessidade de afrontar o quesito acerca das "essências". Perdida a ilusão de um autossuficiente ubi consistam filológico, a partir qual seja possível configurar de modo correto os diferentes, o pensador envolve, em uma mesma substância fluida de comoção, todos os possíveis eu, individuais e coletivos, e, no movimento magmático contínuo destes, enquanto entes criativos, vê tanto suas barreiras tornarem-se permeáveis quanto a exposição nítida das essências das suas experiências. Trata-se de uma permeabilidade por nitidez de essência. As festas são assim os instantes em que adquire visibilidade o movimento emocional criativo que, de outro modo, perdura invisível. A diferença radical entre instantes festivos e instantes não festivos, sobre a qual de maneira especial insiste Kerényi, coincide com a diferença radical entre visível e invisível; enquanto instante de visibilidade (do centro da coletividade, do seu movimento criativo de comoção), a festa é abissalmente não quotidiana. Ao menos sob tal aspecto, a diferença é mais profunda do que aquela entre sagrado e profano (ou abre uma nova profundidade na diferença entre sagrado e profano), uma vez que no sagrado podem ingressar o visível e o invisível, a experiência do ver e a ausência dela: entre visível e invisível, o sagrado e o profano podem - ambos - servir como denominadores comuns, enquanto na experiência festiva o não visível é rechaçado para além das bordas externas da coletividade. Na festa, a coletividade é exposta nua à vista, como um bloco em que centro e periferia se identificam.

Essa interpretação da experiência festiva procede gnosiologicamente da função da festa à sua essência; não tanto da função da festa dentro da coletividade em que se desenvolve quanto da função da festa enquanto zona de organismo vivo, não reparada pelas mais grossas concreções do diferente, com o qual pode entrar em contraste o organismo do pesquisador, que assim experimenta conscientemente uma espécie de osmose emocional a partir dos êxitos gnosiológicos. 
É verdade, além disso, que no estudo de Kerényi o valor da essência da festa por si mesma, como ens quatenus ens, é muito mais privilegiado do que em outras pesquisas similares e garante à investigação certa fineza - justamente do ponto de vista epistemológico: dos limites de cognoscibilidade da experiência festiva - de outro modo ausente. Aqui não pretendemos afirmar que a definição da festa como ens quatenus ens seja especialmente respeitável, uma vez em absoluto verdadeira. Antes, observamos que tal definição revela uma precisa consciência dos limites de cognoscibilidade, da nossa parte, da experiência festiva: da vacuidade das pretensões de conhecer a intrínseca essência do diferente com os instrumentos científicos de que dispomos.

Um testemunho ulterior e menos refinado desse processo de pesquisa que determina a aproximação da festa a partir da sua função vantajosa em face da relação científica - limitada a priori - com o diferente, encontra-se na tradução, realizada por Mario Untersteiner, de um excerto da Política de Aristóteles. No livro As origens da tragédia e do trágico ${ }^{4}$, Untersteiner examina a passagem da Política ${ }^{5}$ em que Aristóteles fala daqueles que se abandonam a

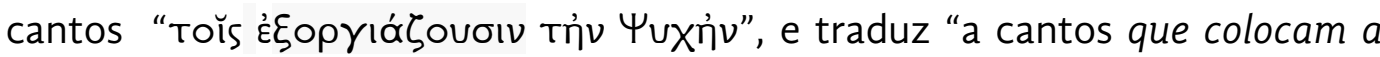
alma em um estado de festividade". O modelo cognoscitivo da festa, com a marca de Kerényi, aqui serve a Untersteiner como passe-partout (o que não quer dizer, a priori, que a operação seja ineficaz e nem mesmo que seja arbitrária) para configurar também a experiência em que Aristóteles indicava a circunstância propícia para a íatpeía e para a Xó9apoıs. A escolha deliberada de um uso da festa como conceito que serve se destaca com o confronto da tradução de Untersteiner com a de Henri Jeanmaire ${ }^{6}$ : "de cantos que lançam a

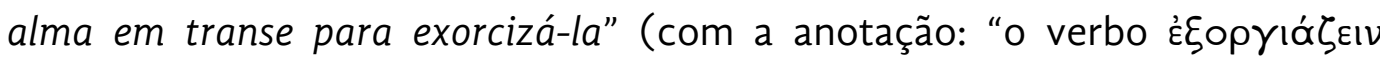
implica a participação em um rito orgiástico para colocar fim - assim parece - em algo"). Na tradução de Jeanmaire é evidente o uso de um outro passepartout: os resultados das pesquisas sobre as experiências religiosas como fatos psíquicos e, com frequência, psicopatológicos. Aliás, não se trata aqui de colocar em dúvida a legitimidade de passe-partout metodológicos ou eruditos (o nosso afrontar o problema do ponto de vista epistemológico é também ele um passe-partout), mas sim de caracterizar as circunstâncias que presidem a

\footnotetext{
${ }^{4}$ UNTERSTEINER, Mario. As origens da tragédia e do trágico. Torino: Einaudi, 1955, p. 101-21; Cf. SEPPILLI, Anita. Poesia e magia. Torino: Bocca, 1962, p. 261-262.

${ }^{5} 1342$ a $1-16$.

${ }^{6}$ JEANMAIRE, Henri. Dionysos. Payot, Paris 1951, p. 319 (Cito a partir da edição italiana traduzida por GLAESSER, Gustavo. Dionysos. Torino: Einaudi, 1972, p. 318).
} 
escolha de um ou de outro passe-partout e, portanto, de tornar saliente a interação, que tais escolhas revelam, entre determinadas situações dos pesqui-

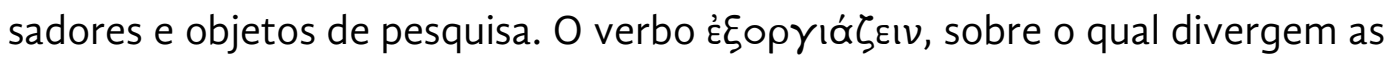
traduções de Untersteiner e de Jeanmaire, é, presume-se, suscetível de muitas outras versões. Por certo, e é isso que a nós é interessante notar, o uso do modelo kerényiano da festividade não é em absoluto obrigatório e, em Untersteiner, denuncia uma ligação oposta àquela de Jeanmaire. Para Jeanmaire, Dionísio e o dionisismo são hoje fundamentalmente inatuais: a fratura entre o eu do pesquisador, como parte da sua coletividade, e o objeto da pesquisa é completa; não há ponto de contato verdadeiro, zona de organismo verdadeiramente nua de concreções, acessível. O passe-partout usado por Jeanmaire não serve como programa para estabelecer um contato, mas apenas para circunscrever as aparências externas de um fenômeno já inatingível na sua essência. A interação entre análise histórica e análise psicológica ou psicopatológica vale unicamente para determinar as bordas externas do dionisismo: aquilo que, do dionisismo, não é essência, mas reatividade humana em jogo aqui como em outro lugar. Para Untersteiner, e ainda mais para Kerényi, os antigos, os diferentes, ainda permanecem sempre acessíveis na sua inatualidade: não se poderá apreender in flagranti a primordialidade, que é primordial atualidade, das suas experiências, mas ainda será sempre possível aceder ao núcleo de tais experiências quando este, nos "momentos sublimes", revela-se visivelmente núcleo e ao mesmo tempo confim, paradoxalmente intimidade e exterioridade, de uma experiência humana sempre repetida quanto à sua essência, não apenas quanto aos materiais reativos humanos que envolve. A inatualidade - para repetir mais uma vez a expressão de Nietzsche com a qual Jeanmaire conclui sua obra - é sintoma, para Kerényi, não de barreira entre o eu e os diferentes, mas de singularidade milagrosa, visionária, epifânica, do tornar-se aparente da comoção. Tal comoção não pode ser colhida na sua essência, nem ontem, nem hoje, com os instrumentos da pura e simples filologia, mas não é a priori preclusa na medida em que sobrevive no hoje sua qualidade criativa. Quem se aproxima no "calor" e na "frescura" da criação, a ela pode ter acesso; nessa faculdade e na tensão dialética das acepções da sua atuação consistem a graça e a medida do operar artístico.

4. Até agora insistimos em declarar que o uso do modelo cognoscitivo da festa, peculiar a Kerényi, mas também a Rousseau, como passe-partout, a priori não é ilegítimo e que nem mesmo ilegítimo é, nesse caso, o proceder 
gnosiologicamente da função à essência. A interpretação da festa a que se chega por essa via apresenta a vantagem concreta de sublinhar a relação entre festa e visão, portanto, de configurar a festa em um âmbito - o da visão - que muito foi descuidado, et pour cause, durante as pesquisas modernas sobre os diferentes. $\mathrm{O}$ uso desse passe-partout ou desse procedimento seria ilegítimo se conduzisse a uma forma de consciência absolutamente fechada: isto é, se em troca das vantagens que custodia, exigisse reafirmar como verdades verdadeiras os limites de situação nos quais torna útil. De fato, ao contrário, assim não é. Colocar a festa no âmbito da problemática da visão significa, antes, favorecer a manifestação da crise pela qual os limites da situação de utilidade do modelo da festa descrito existem não como verdades verdadeiras da experiência festiva, mas como circunstâncias contingentes de dificuldade do conhecer tal experiência.

A festa como ocasião de visão - como ocasião de ver, não de ser vistos é um conceito por meio do qual os historiadores das religiões, os etnógrafos e os folcloristas acumularam uma quantidade enorme de materiais. Em termos paradigmáticos, os historiadores das religiões individualizaram em um grande

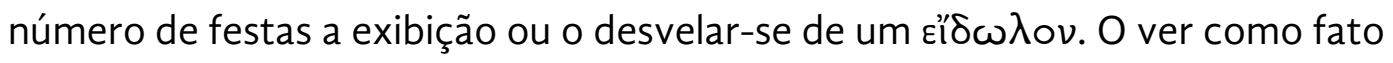
festivo e, antes, como essência da festa, permaneceu todavia em segundo plano. Que a festa seja essencialmente visão é um conceito em relação ao qual os estudiosos deram com frequência um passo atrás. Uma primeira dilação à qual se deve esse estado de coisas pode consistir no próprio fato de que o conceito de festa tenha sido por primeiro afrontado no âmbito da etnografia, e que os protagonistas da etnografia que se iniciava tenham tido com as festas dos "selvagens" relações essencialmente visuais: eles viram as festas dos diferentes, não viram o que os diferentes viam. Viram-nos ver, não viram o objeto da visão ou, ao menos, não os viram com os olhos dos videntes, mas apenas com os olhos dos voyeurs. E uma vez que o conceito de festa, pelas razões indicadas, parece eleito como âmbito de permeabilidade dos diferentes, aquilo que colocava reservas muito graves em face dessa permeabilidade foi lançado às margens das investigações. Se a pesquisa sobre a festa procurava fornecer bases objetivas a uma experiência que desse uma saída à crise do princípio de individualidade, a componente visionária da experiência festiva devia permanecer à parte. Em primeiro plano, ela arriscava prejudicar a priori, por causa da sua inacessibilidade, o êxito e a utilidade da pesquisa.

No centro da festa do povo Rousseau coloca um símbolo anicônico: não 
um zí $\delta \omega \lambda \circ v$, mas "uma haste com uma guirlanda de flores". Lendo as crônicas e observando as figurações da festa da Razão e da festa do Ser Supremo, tem-se, antes de tudo, a impressão de que o que faltava nas práticas cultuais da revolução francesa era precisamente a visão: não a visão oferecida pelos participantes da festa (posto que, de outro modo, ela resultava programada e encenada com especial cuidado), mas a visão de que deveriam gozar os participantes da festa. Estes se faziam ver, não viam. Ao organizar as festas da revolução os teóricos dos novos cultos haviam involuntariamente refletido as deficiências dos etnógrafos que viram os "selvagens" no ato de ver, mas que não conseguiram ver o que os "selvagens" viam. Os participantes das festas da revolução, ordenados em grandes massas de povo segundo sábias coreografias neoclássicas, eram dispostos pelos organizadores como se toda experiência festiva consistisse em uma recíproca exibição uns aos olhos dos outros. Nenhum deles via ou presumia ver mais do que os outros mostravam de si aos seus olhos. E todos se exibiam com a consciência de que a visão, na experiência festiva, não era mais do que um recíproco mostrar-se de todos os componentes da coletividade. Fez-se, é verdade, "dos espectadores um espetáculo", segundo as palavras de Rousseau; mas o espetáculo dessa forma encenado não atingia a essência autêntica do conceito rousseauniano: ainda era sempre uma representação: uma coletividade que se reúne para representar uma festa. O ritualismo das coreografias, dos gestos, dos costumes, dos cantos, constituía o fundamento essencial de similares representações de festas e era muito distante do espontâneo ser antes que representar, típico das festas dos "selvagens" e da sua intrínseca qualidade visionária. Ser antes que representar, ver antes que se exibir: dessas presumidas características fundamentais das festas dos "selvagens" não restava nada. Os participantes das festas da revolução eram reduzidos à condição que os primeiros etnógrafos conseguiram observar nos "selvagens": membros de uma coletividade que, em situação festiva, exibe-se (não "vê"). O fazer-se ver dos "selvagens" era um elemento do fenômeno festivo que resultava permeável aos "civilizados", acessível aos seus olhos; a visão experimentada pelos "selvagens" não era acessível aos "civilizados" e era excluída. Caso se reconhecesse que a essência da festa consistia nessa visão, a experiência festiva teria sido implicitamente julgada inacessível aos "civilizados": a festa, ou melhor, o modelo cognoscitivo da festa usado pelos etnógrafos setecentistas, não mais teria servido para garantir permeabilidade entre coletividades diversas, nem entre o eu e o outro. 
Um modelo gnosiológico entra em crise no instante em que se revela inapto ao seu objetivo: ao seu objetivo de conhecimento não desinteressado; ou no instante em que apenas o objetivo perde necessidade e atualidade. $O$ modelo da festa como experiência do aflorar do centro da coletividade (e do seu aderir por expansão-totalização às bordas externas da coletividade), ao ponto de configurar-se, antes de tudo, como experiência de um fazer-se ver, serviu até quando se tratou de reencontrar na festa um momento da existência coletiva especialmente privilegiado para sua permeabilidade. Ele primeiro entrou em crise no âmbito do esoterismo que procurava de modo pragmático a permeabilidade do diferente exatamente na visão, na experiência do desve-

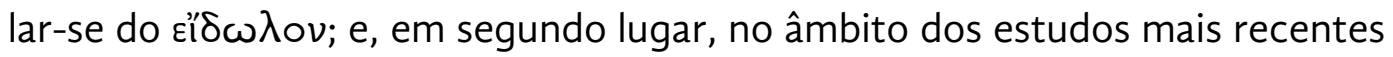
sobre visão, que nascem de uma situação oposta: a de quem reconhece a priori a impossibilidade presumida da permeabilidade entre eu diversos, coletividades diversas e, portanto, preocupa-se sobretudo em traçar, por negação, os confins das próprias faculdades cognoscitivas.

Quanto ao primeiro âmbito da crise, podemos nos referir - para permanecer, por comodidade de materiais, no setor já estudado - às singulares relações entre filões esotéricos e religiosidade de estado durante a revolução francesa. É significativa a esse respeito a reação negativa de um Saint-Martin diante do encenar-se da revolução: o radical antirritualismo (para o benefício da visão) maturado em Saint-Martin contra o fazer-se ver das festas republicanas. E também algumas disposições de grupos opostos ao culto do Ser Supremo, como os Hsd ("Hommes Sans Dieu"), organizados por Sylvain Maréchal, que se reuniam em um templo em cujo fundo havia um véu branco com a inscrição: "De toutes les erreurs, la plus grande est un dieu" ${ }^{7}$. Seu ateísmo ritualizado remontava, de um lado, à posição já notória nos círculos girondinos e, por outro, e de modo mais subterrâneo, a formas de ateísmos místicos que se conectavam ao antinomismo e ao ateísmo místico hebraico dos Frankistas: refutação de coligar o divino com o fazer-se ver e afirmação selada de visões conexas, paradoxalmente, a um divino que é preciso misticamente negar o ser. ${ }^{8}$

Quanto ao segundo âmbito de crise do modelo de festa como fazer-se ver,

\footnotetext{
7 Em francês, no original. Tradução: “De todos os erros, o maior é um deus". (n. t.)

${ }^{8}$ Sobre tal problema nos debruçamos sobre o volume JESI, Furio. Mitologie intorno all'illuminismo. Milano: Edizioni di Comunità, 1972, p. 17-40, p. 79 (Frankistas), p. 129-33 (SaintMartin).
} 
será oportuno referir-se à crise mais geral que marca hoje a etnologia e a antropologia cultural: crise de confiança na possibilidade de conhecer os diferentes, crise da qual as ciências humanas parecem em acordo tirar a conclusão de um novo objetivo: não mais conhecer o diferente, mas conhecer as modalidades de incognoscibilidade do diferente. Do ponto de vista da história do pensamento científico, precisamente este parece ser o aspecto mais significativo (mas também menos explícito) do estruturalismo: construção de um complexo de modelos gnosiológicos sobre as bases da impossibilidade de conhecer por permeabilidade; retorno explícito, por um lado, à crise rousseauniana do princípio de identidade e sua apologia como estado de graça do etnólogo; por outro lado, negação implícita da possibilidade de conhecer o diferente a não ser pelo trâmite de arquiteturas conceituais verdadeiras como constantes no nível do "universalmente humano" nas suas articulações antropológicas e espaço-temporais, inservíveis no nível de diferenças entre o eu e os outros que não podem ser conduzidos a essas constantes.

A experiência festiva é assim configurada em esquemas organizativos de gestos, de espaços e de tempos, cujo valor aos olhos do pesquisador consiste, antes de tudo, na sua generalidade. E essa generalidade de estrutura deslocase muito facilmente para os níveis de ontologia: "é possível perguntar observa A. Frigout $^{9}$ - se o espaço das festas não põe à luz uma constante da vida social da qual se encontram analogias não apenas no mundo da 'vida', mas também no do 'ser'”. A preocupação ontológica é, de resto, sempre latente por trás da metodologia estruturalista, ainda que nem sempre venha denunciada em termos tão explícitos. Além das constantes do humano (da "vida" humana), manifestam-se por transparência, ou é suposto que se manifestem, constantes existenciais que representariam a contraparte do sacrifício que parece ser da cognoscibilidade (por permeabilidade) dos diferentes, e é da cognoscibilidade (por permeabilidade) do humano. Os etnólogos e os antropólogos deveriam ser os primeiros a não se contentar com o "universalmente humano" e, de fato, com isso não se contentam na medida em que além deste visam o "universalmente existente". Esse sacrifício do humano se traduz em uma espécie de reificação: o homem é conhecível enquanto "coisa" do universo, "coisa" da natureza, "coisa" do universo vivente diante do qual Rousseau sentia esvair os limites do seu eu. O conhecimento por permeabi-

\footnotetext{
${ }^{9}$ FRIGOUT, Arlette. L'organisation de l'espace dans les fêtes: méthode et théorie. Annuaire de la V Section de l'Ecole Sup. des Hautes-Etudes, v. LXXVII, p. 117, 1969-70.
} 
lidade dá lugar ao conhecimento por reificação, por parte de uma entidade cognoscitiva que surge autorreificando-se. Se no iluminismo a festa servia como instante de permeabilidade gnosiológica da coletividade, e como tal continua a servir - para citar um exemplo especialmente significativo - no âmbito de pesquisas marxistas que recuperam a gnosiologia e a antropologia iluministas, com o estruturalismo a festa torna-se útil como repertório de "coisas viventes", compreendidas as "coisas" humanas, os participantes humanos da festa: "coisas" que se tornam salientes na sua reificação durante o momento privilegiado, festivo. Desse modo, de resto, religamo-nos ao filão de estudos que reconhece na festa, ou ao menos em determinado modelo de festa, o desvelar-se de um عí $\delta \omega \lambda$ ov, de uma "coisa", pedra, madeira, ou melhor, ao mesmo tempo, nem pedra, nem madeira, nem simulacro, mas "coisa" vivente por excelência. "Coisa" e visão são enlaçadas no âmbito da experiência festiva assim configurada - diga-se que a visão é compensação de valor da "coisa" como símbolo profano do resultado da produção, ou que a visão é transvaloração da experiência de estraneidade nos confrontos das "coisas" da natureza. E isso que assim, ou também em muitíssimos outros modos, pode-se dizer, conserva uma validade muito precária, uma vez que seu fundamento depende da não-veridicidade autônoma da visão, da explicação ou do trivializar-se da visão em termos de psicologia.

5. Se a visão festiva fosse verdadeira... Mas em todos os pontos de vista metodológicos que examinamos até agora, a autônoma veridicidade da visão festiva é colocada entre parênteses como inacessível ou explicitamente negada, de maneira diferente da interpretação de Kerényi. Já ao confrontar essa situação científica a propósito dos mistérios de Elêusis, mesmo que de modo indireto, Kerényi se preocupou em traçar uma via epistemológica diversa da seguida por Walter F. Otto: uma via que leva ao "saber sem palavra" antes que ao "milagre"

A verdade - se em Elêusis uma verdade era revelada aos iniciados em imagens, sinais e palavras - devia ser algo de absolutamente novo e surpreendente que não era possível conhecer apenas com os meios da razão e da experiência. Assim acreditou Otto, e a característica de menina e mulher, própria de Deméter, é efetivamente uma coisa desse gênero. Mas essa verdade, traduzida na linguagem da realidade quotidiana e não festiva, a Otto não parece misteriosa o sufici-

\footnotetext{
${ }^{10}$ KERÉNYI, Károly. II miracolo di Eleusi. In: KERÉNYI, Károly; JUNG, Carl G. Prolegomeni allo
} studio scientifico della mitologia. Torino: Einaudi, 1948 [Torino: Boringhieri, 1972], p. 255. 
ente para formar o conteúdo de um tão grande mistério. Ele acha banal o saber sobre o fato de que o homem deve morrer, mas sobrevive nos próprios descendentes. E de fato é assim, no que diz respeito ao "saber sobre" isso. Mas há uma imensa diferença entre o "saber sobre algo" e o "saber e ser algo". Uma coisa é saber sobre a semente e a germinação, outra é ter reconhecido na semente e na germinação o passado e o futuro, como a própria existência e a própria continuidade...

O "saber sem palavras", o "saber e ser algo" são determinações da visão festiva no nível gnosiológico. A via traçada por Kerényi leva, aliás, por certo não à experiência desse "saber sem palavras", mas à consciência de que o saber sem palavras mostra-se "justamente naquele lugar, em um determinado período da existência do mundo". Sobre as razões de utilidade de tal consciência já nos debruçamos; ela entra em crise no momento em que se revela escassamente útil. Se ela assim se revela, como muitos sinônimos indicam, o discurso, a investigação, a hipótese de trabalho não podem ser senão determinações mais ou menos acuradas das modalidades de incognoscibilidade e da sua utilidade diversa.

O problema epistemológico que de tal modo se propõe pode ter, além de uma raiz geral na atualidade da experiência científica, uma raiz particular na história da festa. Pode acontecer, com efeito, que hoje a cognoscibilidade da essência da festa esteja perdida, uma vez que, hoje, "em um determinado período da história do mundo", a própria festa tornou-se impossível. Uma primeira verificação dessa hipótese consiste na constatação do abismo existente entre tudo o que hoje se define "festa" e aquilo que é possível supor que foram as festas antigas. Não sabemos o que foram na sua essência, mas podemos avançar algumas hipóteses sobre o que não foram e, com base em tais hipóteses, somos levados a excluir que existam parentescos prováveis entre festas hodiernas e festas antigas.

A determinação cronológica "hoje" deve ser compreendida em sentido mais amplo: "hoje" (nesse discurso) é o instante em que vivemos, mas também o tempo da festa do Ser Supremo presidida por Robespierre em relação ao "ontem" que foi o tempo das Grandes Panateneias, da festa observada no Brasil no século XVI por Jean de Léry ${ }^{11}$, da Festa dos Loucos do Medievo cristão. "Hoje" é o tempo da festa que Antonin Artaud se propunha encenar com o Teatro da crueldade, em relação ao tempo da "festa" cruel que Lucrécio

${ }^{11}$ LÉRY, Jean de. Le voyage au Brésil (1556-1558). Paris: Payot, 1927, p. 223. 
evocou no fim de De rerum natura sob o disfarce da peste de Atenas. O que não eram tais festas, enquanto as festas de hoje o são? Antes de tudo, não eram festas em que, como nas de hoje, estivesse ausente a visão: o ver, ser e custodiar o ver (ser para custodiar o ver), que hoje é deliberada ou inevitavelmente excluído. É possível se objetar que não faltam nem mesmo hoje festas em que o fator da "autossugestão" (isso que, por razões de comodidade, assim é definido) e o uso de substâncias alucinógenas determinam "visões". E, todavia, tais "visões" hodiernas não vão além do equivalente das observações dos primeiros etnógrafos: víamos ver, mas não víamos o que os outros, os diferentes, viam. Quem hoje "vê" em experiências festivas, seja sob o influxo da "autossugestão" ou de substâncias alucinógenas, de fato não vê, mas se vê ver, sem ver o objeto da visão, que não existe. Vê-se ver, não vê, pois seu ver não tem nenhuma relação com o ser conscientemente no instante privilegiado

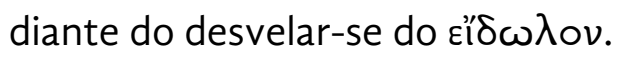

É necessário especificar que, aqui, a palavra eí $\delta \omega \lambda$ ov, nessa acepção, é o simulacro de Artemisa de Éfeso, mas também o barco a vapor no rio Murray que os indígenas australianos "representam dançando" diante dos olhos de R. R. Marett ${ }^{12}$. Eı́ $\delta \omega \lambda$ ov é, portanto, a "coisa" que se faz visível no espaço que intercorre entre os homens e os deuses. A existência desse espaço é condição

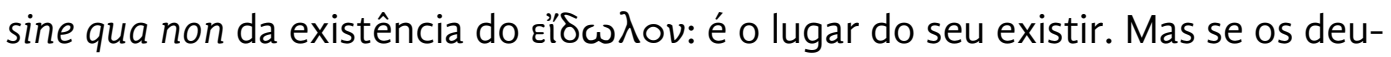
ses se distanciaram "nas profundidades do seu nada" (para usar a expressão do cabalista medieval), tanto que o espaço entre eles e os homens se tornou

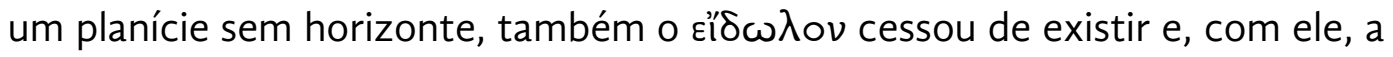
visão. O espaço entre homens e deuses é o lugar de existência do $\varepsilon^{\prime} \delta \omega \lambda{ }^{\prime} \nu$ até o ponto que possui horizonte; para que o $\varepsilon^{\prime} \delta \omega \lambda$ ov exista é preciso que esse espaço tenha, se não um limite objetivo, uma ilusão óptica de limite: tal ilusão

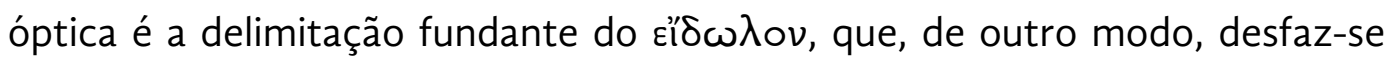
numa sombra ou numa luz privada de confins e, portanto, não pode se desvelar. Pode acontecer que as palavras de Nietzsche, "Deus está morto", não sejam apenas verdadeiras para o hoje em que Nietzsche as pronunciou; mas, para que o $\varepsilon^{\prime} \delta \omega \lambda$ ov exista, é preciso que tais palavras não sejam pronunciadas. Se elas ressoam, significa que a ilusão óptica do horizonte do espaço

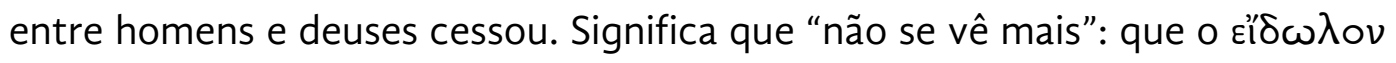
não é mais disponível na sua desvelabilidade, na qual consiste seu existir.

\footnotetext{
${ }^{12}$ MARETT, Robert Ranulph. Faith, Hope and Charity in Primitive Religion. Oxford: Oxford Univ. Press, 1932, p. 32.
} 
Quem hoje se persuadiu de "ver" durante a experiência festiva, por certo não está disposto a aceitar a palavra de Nietzsche. Todavia, ao menos no âmbito da festa, sua pretensão se revela infundada na medida em que se baseia não no estranhamento pela ontologia, a respeito da qual Nietzsche disse a agressiva negatividade em relação à vida de Deus, mas sim em uma recuperação da própria ontologia em termos de esquecimento da consciência. Antes de ser "carrascos de si mesmos", os "videntes", que hoje parecem viver experiências festivas, encontram no esquecimento do conhecer uma singular via

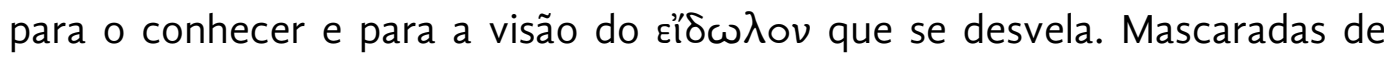
experiências de conhecimento de todo diferentes, as festas de hoje, sejam hoje ligadas ou não a determinadas doutrinas ou organizações religiosas, são múltiplas variações do esquecimento do conhecer "racional", "iluminista", e não certamente alternativas a ele. São estados em que o conhecer "racional" (usamos aqui e em outras vezes o qualificativo racional com o sentido de "razão iluminista") se dilui até o esquecimento de si, mas não é efetivamente negado. Uma negação de tal gênero, para ser de fato, deveria envolver todo aspecto da existência e encontrar justo no seu valor totalizante o sentido do seu colocar-se contra. Ao contrário, as festas hodiernas não são senão pausas, períodos em que o conhecer racional se desagrega temporariamente em esquecimento de si, pronto para recompor-se e a assumir, um instante depois, terminada a festa, a situação de privilégio que permaneceu sempre sua em latência. Daí, aliás, a insistência dos estudos sobre a festa de "ontem" (dos antigos, dos "primitivos") como suspensões do tempo, pausa do tempo histórico, epifanias de tempo dos primórdios que perenemente retornam. A dialética temporal que forma o esquema de grande parte dos estudos modernos sobre a festa (e sobre o mito) é o preciso reflexo de uma situação atual: da "festa" de hoje sobre a imagem da festa de ontem. Hoje, dificilmente a festa pode ser compreendida senão como uma suspensão do tempo histórico, a qual coincide com a irrupção cíclica de um tempo de qualidade particular: tempo primordial, tempo das origens, tempo de regeneração, tempo criativo etc.. O modelo cognoscitivo da situação atual de crise é o único disponível para fornecer definições positivas da festa de ontem ou da festa de sempre. $O$ vínculo entre tempo histórico e conhecimento racional mostra-se tão forte, ainda que em crise de valor, a ponto de induzir a definir e a praticar a festa seja como esquecimento do conhecer, seja como suspensão do tempo histórico. Se não se leva em conta tal vínculo e ao se interpretar a festa de ontem 
como um instante de visão no tempo histórico, não como um suporte de outro material dentro do tempo histórico, mas como instante de epifania de um elemento - a visão - homogêneo em relação ao tempo histórico, imediatamente se está obrigado a calar: essa interpretação, com efeito, logo se traduz em definição apenas por negação: a festa de ontem não era nada similar à festa de hoje - o que era ela, não podemos saber. O que pode ser a visão homogênea ao tempo histórico não nos é possível saber, uma vez que nos encontramos na impossibilidade absoluta de nos colocar em qualquer relação com um âmbito de referência em que a expressão "visão homogênea ao tempo histórico" tenha um sentido. Nossa situação volta a ser de todo idêntica àquela dos primeiros etnógrafos: vemos ver, não vemos o que é visto pelos que veem. Ou, de maneira mais exata, vemos os traços de alguns que viram; não vemos nenhum traço do que eles viram.

6. Etnologia e história das religiões recolheram numerosos testemunhos a partir dos quais se conclui que as festas dos antigos e dos "primitivos" eram ligadas a uma série de tradições mitológicas sobre a própria origem das festas. As festas aparecem, sob essa luz, como instantes salientes e exemplares de epifanias míticas, horas mitológicas recorrentes na vida das coletividades. Além da problemática da festa, destaca-se assim a problemática da mitologia, sem a qual permanece precária toda consideração sobre a essência da festa, mesmo que seja apenas sobre nossos limites gnosiológicos em relação à essência da festa.

Não há sentido, de fato, em usar uma expressão como "visão homogênea ao tempo histórico" sem se referir à mitologia, que é o único âmbito de estudos no qual é possível chegar não à significância de tal expressão como sigla de modelo gnosiológico efetivamente útil, mas, ao menos, a algumas reflexões sobre as modalidades de não-conhecimento que tal modelo indica. Essas possibilidades, intrínsecas aos estudos sobre a mitologia, oferecem também algumas justificações ao fato de nos debruçarmos sobre a expressão "visão homogênea ao tempo histórico", justamente para discutir a cognoscibilidade (ou a não-cognoscibilidade) da festa. Também esse debruçar-se - é preciso admitir isso de modo explícito - é, por si só, em parte arbitrário. É arbítrio da nossa parte ao supor que, à diferença das festas de hoje, as festas de ontem estivessem em alguma relação com a visão homogênea ao tempo histórico, ou, pelo menos, não a excluíssem. Tal arbítrio encontra justificação, como arbítrio talvez útil para formular uma hipótese de trabalho não absurda a 
priori, se nos coloca no âmbito dos estudos sobre a mitologia. Diferentemente do mito, a mitologia é algo que por certo existe, e desde há muito tempo, desde "ontem". É algo que existe, que funciona - como uma máquina - e que com seu funcionamento constitui um denominador comum entre tempos e culturas em que existe espaço para a presença do عí $\delta \omega \lambda$ ov e tempos e culturas em que tal espaço não existe. Esse denominador comum permite, em tempos e em culturas nas quais não há espaço para a presença do eî́ $\omega \omega \lambda$ ov (tempos e culturas nas quais valem as palavras de Nietzsche), ao menos debruçarse sobre as modalidades de não-conhecimento que caracterizam então o uso do modelo gnosiológico determinado pela cifra "visão homogênea ao tempo histórico".

A mitologia não é uma máquina que funciona apenas enquanto os homens estão persuadidos de que "deus está vivo". Ela continua a funcionar também onde e quando os homens estão persuadidos de que "deus está morto", e onde e quando os homens, ainda que não persuadidos de que "deus está morto", permanecem ligados sem argumentos de oposição aos pressupostos dos quais procede necessariamente essa persuasão. Uma ilustração por via negativa dessa prerrogativa da máquina mitológica pode trazer exemplos de uma situação, como a grega, em que a mitologia parecia especialmente ligada à experiência do divino: à persuasão do divino (isto é, à condição criada pelo divino que persuade). A mitologia grega parecia vinculada indissoluvelmente aos deuses gregos e destinada a sucumbir (ou a durar apenas como uma ruína, não por certo como uma máquina que funciona) com a "morte" dos deuses gregos. Ao se falar de mitologia grega com consciência rigorosa do significado e das implicações dessa expressão, o vínculo entre mitologia grega e deuses gregos resulta indissolúvel. Mas a própria expressão mitologia grega é questionável quando usada no seu significado mais rigoroso, uma vez que implica uma precisa autonomia da mitologia grega em face de outras presumidas autônomas mitologias, e impede de afrontar o conceito de máquina mitológica na sua inteireza. A rigor, nós não acreditamos ser lícito falar de uma mitologia grega, mas de uma máquina mitológica que funcionou na Grécia e funciona em qualquer outro âmbito de cultura humana por nós relativamente conhecido (por exemplo: as culturas pré-históricas com frequência não são por nós conhecidas suficientemente desde esse ponto de vista e, portanto, não podemos levantar hipóteses muito fundadas sobre a presença e funcionamento da máquina mitológica nelas, em relação com elas). Não acreditamos ser lícito 
falar de uma mitologia grega, assim como não acreditamos ser lícito - se não admitimos limites de diferenciação muito exíguos - falar de um estômago grego, de um fígado grego, de pulmões gregos. A máquina mitológica é algo que existe funcionando em relação com uma parte da humanidade relativamente ampla, ainda que - para limitar a metáfora precedente - não haja elementos certeiros para afirmar que ela seja algo universalmente humano como o estômago, o fígado, os pulmões etc.

No âmbito da Grécia antiga, a presença da máquina mitológica em funcionamento parece ligada à presença dos deuses gregos. De fato, não é assim, e a esse equívoco induz seja a concepção de uma mitologia grega, seja o equívoco entre mito e mitologia. Partindo do que sabemos da cultura grega, poderemos compreender o mito como o que preenche a distância entre homem e deus: substância etérea na qual se projetam e acham um ponto de encontro imagens do divino e do humano, encolhendo-se as primeiras, engrandecendo-se as segundas, pelo oposto resultado do seu acontecer, que as projeta para fora do seu objeto e as afasta dele. Afastada do divino, a imagem do divino, que por si só é totalidade, faz-se mais exígua, adquire dimensões parcialmente apreensíveis pelo olhar do homem; afastada do humano, a imagem do humano, que por si só é exiguidade, amplia-se, atinge confins remotos nos quais encontra as hierofanias. Mitologia significa narrativas em torno de deuses, seres divinos, heróis e descidas ao Hades.

Mas falar do mito como de uma substância etérea, na qual se projetam imagens, quer dizer criar um mito do mito. Se a mitologia, enquanto narrativa, é em certa medida substância, não é substância o mito, aquilo que recebe substância da mitologia. Enquanto narra, o mitólogo cria uma substância, a narrativa, pressupondo a existência de outra substância, o mito, e tendo a sensação de plasmá-la. Mas o mito não tem substância fora da mitologia, e a partir do instante em que adquire substância é mitologia, não mito. O mito é, portanto, a mitologia? Assim o é na medida em que só o que tem substância é. É possível todavia falar do mito sem identificá-lo com a mitologia, se é conveniente falar daquilo que não é: do vazio que está entre o divino e o humano. Nesse vazio projetam-se as imagens do divino e do humano que dizemos mitológicas porque se projetam sobre ele: dele retiram nome e a ele levam como uma ponte não terminada leva ao abismo.

Na língua grega o abismo tem um nome, Caos, que alude precisamente ao seu ser escancarado. Em tal abismo primordial se projetam as imagens dos 
deuses e dos heróis, que todavia não o podem mais superar e, portanto, levam a ele, ao sempre escancarado e à sua perene primordialidade. Mesmo o abismo projeta sobre si a própria imagem, que tem a aparência de uma divindade: na cosmogonia órfica é a Noite, em Hesíodo é a Terra, ambas "mães de sonhos". O abismo possui uma qualidade espaço-temporal, ainda que em negativo: espaço que não é, tempo que não é: e tal qualidade aflora em positivo nas suas duas imagens-filhas, Noite e Terra. A primordialidade, que é perene impassibilidade, do abismo reúne não-espaço e não-tempo no abismo, espaço e tempo nas filhas dele. Noite, Nyx, é tempo de trevas, mas é também lugar de trevas: um ventre que pode ser fecundado e uma "casa terrível". Terra, Gaia, é lugar sobre o qual e no qual tudo existe: mas há também um tempoTerra, a hora em que os sacerdotes de Dodona dormem sobre a nua terra, a hora dos sonhos que nascem da Terra e da soberania de Terra, enquanto seu consorte celeste luminoso é invisível: a noite, que é tempo-Terra em vez de Nyx em um sistema mitológico no qual, das duas imagens de Caos, prevalece Terra, Gaia. Desse modo, onde Nyx prevalece, a terra é lugar-Noite. Ambas "obscuras", "negras", Terra e Noite são imagens perceptíveis pelo homem, mas remetem ao não perceptível abismo. Dentre as imagens mitológicas são as mais familiares, mas possuem também um núcleo de irredutível estraneidade: lugar-Noite e tempo-Noite, lugar-Terra e tempo-Terra, são o que conduz à orla da não-existência, ao outro primordial e perene que acabara de se mascarar com a aparência de Tanatos e de Hypnos. Terra e Noite são, para os gregos, as mais bárbaras dentre as divindades: não por que veneradas pelos bárbaros (uma vez que os deuses dos bárbaros são eles próprios aparências dos deuses dos gregos), mas por que neles está presente a barbárie em estado puro, a estraneidade absoluta. Ainda mais neles do que em Hades: enquanto Hades é o deus da morte, Nyx traz consigo Tanatos, a morte, e Gaia contém em si todo o reino dos mortos. A mitologia cria uma imagem percebível da morte com o preço de fazer desta, acima de tudo, um deus; mas Nyx e Gaia não são deusas da morte: são a deusa-Noite e a deusa-Terra que trazem consigo e em si a morte mantida intacta além da parede do seu serem deusas, o que não altera a morte mas, antes, conserva-a indene pela divinização.

Nesse processo é possível obter, de um lado, o aparente sacrifício da realidade em prol do divino, celebrado pela mitologia, de outro lado, a recuperação da realidade mediante o desfrutar do divino, recuperação que determina o sentido daquele "sacrifício" e mostra nele um ato de autonomia da mitologia 
em face do divino. Essa autonomia é o que faz da mitologia o âmbito de estudos mais apropriado para se desfrutar de um denominador comum entre tempos e culturas em que foi verdadeiro um espaço entre o humano e o divino (onde "deus está vivo") e tempos e culturas em que tal espaço não possui verdade, pois não tem limite determinável: uma vez que não existem coordenadas que podem determinar-lhe os pontos ("deus está morto"). Trata-se então de estudar, antes de mais nada, como é feito o modelo gnosiológico indicado pela cifra "máquina mitológica" e, em segundo lugar, estudar como tal modelo nos serve para determinar as modalidades de não-conhecimento intrínsecas no uso do modelo de festa indicado pela cifra "visão homogênea ao tempo histórico".

7. “O mito, em uma sociedade primitiva, vale dizer, na sua original forma viva...": para circunscrever um fato mitológico, etnologia e ciência do mito recorreram muitas vezes à tríade de conceitos designados pelos três adjetivos que aparecem nessa frase de Malinowski: primitivo, original, vivo. A frase de Malinowski é, por si só, documento de uma doutrina enrijecida pela quantidade de postulados que lhe são necessários: primitivo, original, vivo são, nessa acepção, conceitos colocados na impossibilidade de mover em articulação dialética. Eles a priori são ditos rigidamente solidários em um ponto, que é o espaço do mito. Nascida da reflexão sobre os resultados da observação etnográfica, essa doutrina postula o fato de que "em uma sociedade primitiva" o mito cumpra perfeitamente a própria função, portanto, esteja em ato "na sua original forma viva". Propondo-se a explicar a função do mito, de outra maneira que não remetendo pura e simplesmente ao próprio ser do mito, o pesquisador se coloca num caminho que não podemos dizer, até agora, enganado, mas que desvia de uma primeira verificação necessária das relações entre os três conceitos usados para circunscrever o fato mitológico. Colocar como hipótese de trabalho a função puramente ontológica do mito leva, pelo contrário, a interromper a rígida solidariedade de primitivo, original, vivo, e consente observar seu livre jogo no halo do mito ens quatenus ens.

Voltemos à frase de Malinowski, considerando-a, por convenção, ponto de partida do processo (em ato nas pesquisas de outros estudiosos) que oferece mobilidade dialética à tríade. Os três adjetivos que designam os conceitos da tríade suscitam, cada um, vívido significado autônomo. Primitivo adquire significado em um decurso histórico irreversível, e parte da acepção extrema de "cronologicamente primeiro"; original tende a significar "atemporalmente 
fundante"; vivo, enquanto pareceria colocar-se como intermeio ("vitalidade" como característica essencial de fenômenos que são tanto "primitivos no tempo" quanto "atemporalmente fundantes"), alcança a acepção extrema de "genuíno hoje" e, portanto, acena à possível posição mediatriz de original: "atemporalmente fundante" como característica essencial de fenômenos que são tanto "primitivos no tempo" quanto "genuínos hoje". Tal mediação é o pressuposto da doutrina expressada por Kerényi no trecho que já citamos (p. 90) a propósito "daquele elemento de urgência e de comoção que transforma o próprio tempo em momento criativo".

Original é o que serve aqui como mediador entre primitivo e vivo. Mas tal mediação é possível pela particular aproximação que se realizou entre original e mito: aproximando-se de modo particular do mito, original adquire sobre os outros dois conceitos uma soberania (explicada em mediação) que lhe surge a partir do reflexo da pressuposta função ontológica do mito. Por causa da sua origem, tal soberania tende novamente a enrijecer as relações entre os três conceitos: reafirma sua rígida solidariedade ontológica em um ponto que é o espaço do mito. Além disso, acontece se é primitivo, antes que original, a aproximar-se de modo particular do mito e, por isso, a adquirir dele soberania (pense-se em Lévy-Bruhl).

A situação entretanto muda se vivo assume a soberania na tríade. Enquanto primitivo e original não são suscetíveis de investigações empíricas e, desse modo, podem extrair soberania unicamente de sua acentuada proximidade do mito, vivo é identificável com o objeto que a ciência do mito pode estudar também empiricamente: a mitologia, a máquina mitológica na sua presença em funcionamento. Vivo, portanto, pode adquirir soberania (eventualmente explicável em mediação) sobre primitivo e original, sem necessidade de aproximar-se do mito ao ponto de dele sofrer a endurecedora influência ontológica, mas apenas se colocando de modo autônomo como máquina mitológica diante do mito.

Vivo pode tornar-se elemento soberano sobre primitivo e original e, como máquina mitológica, pode englobá-los em si. No interior dele, primitivo e original permanecem entre si em tensão dialética, uma vez que as paredes de vivo, as paredes da máquina mitológica, mantêm-nos abrigados da influência endurecedora do mito. Vivo traça com as próprias bordas os confins dessa tensão: além delas, a tensão não pode alongar-se; no interior deles, a tensão é necessário ritmo vital. Vivo permanece pura mecanicidade, automatismo, se 
ao funcionamento da máquina mitológica não se identifica a tensão entre "primitivo no tempo" e "atemporalmente fundante". Mas nessa situação se descobre que vivo, tornando-se soberano na tríade, descarta primitivo e original contra o mito, ao ponto de juntá-los a ele. Na cena permanecem apenas a máquina mitológica (vivo) e o mito (primitivo, original): de um lado, a "vital" máquina mitológica que funciona, do outro, o objeto da fome mitológica satisfeita pela máquina com seu funcionar. A máquina mitológica não produz mitos, portanto, não satisfaz a fome dos mitos oferecendo-lhes aquilo que, com a própria ausência, suscita a fome. Mas a máquina mitológica oferece ao faminto de mitos seu produto, as mitologias, que acalma parcialmente a fome. A existência da máquina mitológica é empiricamente verificável: e isso não se pode dizer do mito; enquanto a fome de mitos $^{13}$ é empiricamente verificável, não se pode ter nenhuma certeza empírica sobre a existência do objeto de tal fome; enquanto as mitologias são empiricamente verificáveis como produtos da máquina mitológica, a existência do mito se subtrai a qualquer verificação empírica. A máquina mitológica é um dispositivo que com sua presença que funciona, "vital", dá tréguas à fome de mitos sem jamais satisfazê-la por inteiro. Seu funcionar remete incessantemente ao alimento mítico, que, entretanto, permanece inacessível, e, no lugar deste, oferece o alimento mitológico. Assim, seu funcionar termina com o perene remeter também à própria máquina, à sua presença que funciona, do mesmo modo como a satisfação temporária e parcial da fome consiste em colocar a máquina entre a fome e o alimento que o faminto anseia. A própria máquina, na medida em que é comestível, faz-se alimento; mas o faminto não desfruta nem mesmo do outro alimento, cuja ausência lhe gerou a fome. E no instante, continuamente repetido, em que o faminto se nutre da máquina, a máquina se afirma como coincidência de automatismo e de vitalidade orgânica. Quanto a isso que, talvez, faz funcionar a máquina (e, portanto, se existe, torna-a não automática), isso, se em verdade existe, encontra-se escondido de tal modo no interior da máquina, como tensão entre primitivo e original, que os comedores das paredes externas, a eles oferecidas pela máquina, nisso não percebem nem mesmo a mais remota pulsação. Nenhuma vista permite traspassar as paredes da má-

${ }^{13}$ Essa nossa expressão coincide apenas em parte com a análoga usada por ZIOLKOWSKI, Theodore. Der Hunger nach dem Mythos: Zur seelischen Gastronomie der Deutschen in den Zwnaziger Jahren. In: Die sogenannten Zwanziger Jahren. Ed. Reinhold Grimm e Jost Hermand. Zürich: Gehlen-Verlag, 1970, p. 270. 
quina mitológica. Só se pode crer ou não crer na máquina quando ela, pelo próprio fato de funcionar, remete ao mito como àquilo que não existe, uma vez que é demasiado primitivo e original para aflorar no ser. Ao se crer na máquina, pode-se também ir além daquilo que ela diz e supor que "o mito que não existe" esteja no interior da própria máquina e seja o que a faz funcionar: no interior da máquina, nesse caso, estaria uma espécie de Hades do préexistente. E também levando a esse limite a especulação, acaba-se por reconhecer à máquina as prerrogativas que ela tacitamente reivindica: seu ser com as próprias paredes externas a marca de confim do ser.

O que é a máquina mitológica? Definimo-la máquina pois é algo que funciona e, à investigação empírica, parece ser algo que funciona automaticamente. Quanto ao tipo de funcionamento que lhe é próprio, e à função que ela desenvolve, devemos por ora nos limitar a dois grupos de dados. Por um lado, é possível observar que a máquina mitológica é o que, funcionando, produz mitologias: narrativas "em torno a deuses, seres divinos, heróis e descidas ao Hades". Por outro, constata-se que a máquina mitológica é o que, funcionando, dá trégua parcial à fome de mito ens quatenus ens. Com sua presença que funciona, a máquina põe em dúvida essa determinação ontológica do mito, colocando o mito no pré-ser e produz mitologias que não são entes quatenus entes, mas sim entes enquanto produtos da máquina.

Quais são as relações entre a máquina mitológica e os homens que em sua maioria poderiam reivindicar para si a qualificação de máquinas mitológicas, isto é, os mitólogos? Para tentar responder essa pergunta é necessário estudar a origem do fato mitológico. O fato mitológico é um período e um âmbito espacial determinados de funcionamento da máquina mitológica e envolve certo número de homens: os que narram as mitologias, os que as escutam, os que a elas identificam modelos de comportamento. Eles estão no interior ou no exterior da máquina? Ou são eles mesmos a máquina? São eles mesmos a máquina e empregam-se como partes de uma máquina que produz mitologias? Ou são reunidos como partes de uma máquina por uma norma organizativa que exorta à própria atuação, independentemente da vontade deles? Não é possível afrontar essas interrogações sem indagar, como aqui nos propomos a fazer, a origem do fato mitológico, de um fato mitológico. Pelo que se nos mostra até agora, o que é indagável não é a essência da origem, mas a relação entre o fato mitológico e sua origem: referimo-nos, portanto, apenas a esse tipo de pesquisa quando aqui falamos em indagar a origem de um 
fato mitológico. Similar pesquisa significa estudar o funcionamento da máquina mitológica, apanhar o fato mitológico em ato, in flagranti, uma vez que a máquina, com sua presença que funciona, é um constante remeter à tensão entre pré-existente e existente enquanto produto da máquina, entre mito e mitologia, e tal tensão, perenemente irresoluta, constitui a atualidade, o flagrante do fato mitológico. A máquina mitológica é auto-fundante: coloca sua origem no fora de si que é o seu interno mais remoto, seu coração de pré-ser, no instante em que se coloca em ato. Essa pressuposição de origem (o remeter-se ao mito) é totalizante: envolve todos os instantes e os âmbitos espaciais de funcionamento da máquina, uma vez que o fora de si em que a máquina coloca a própria origem é seu centro. Todo fato mitológico é, assim, ele próprio pressuposição da própria origem, que é também a origem da máquina. Existem obras, fatos mitológicos, como a Teogonia, de Hesíodo, em que tal pressuposição se identifica ao máximo com as modalidades constitutivas, organizativas, da própria obra. Em outras obras a pressuposição é implementada em forma negativa, como crítica do mito, e, nas intenções do autor (pensemos sobretudo em Eurípedes), pode servir como decantação purificadora do agir mitológico, conduzida a uma ortodoxa teologia negativa. Em outras, ainda, a pressuposição da origem envolve em escarça medida a vontade consciente do criador-organizador. Essas últimas são as mais úteis para apreender a tensão em ato entre mitologia e mito, portanto, a mitologia em ato, a máquina mitológica na sua presença que funciona. Aí, de fato, ela é tensão em estado puro, não modificada pelos autores com tentativas de resolução que vão da mediação à superação por excesso. Obras do gênero são com frequência, mas não por certo de modo inevitável, alimentadas por mitologias no estado de sobrevivência tardia. Em tal estado, o comportamento das formas mitológicas (dos produtos da máquina mitológica) é com mais frequência marcado por um automatismo que toma a mão do mitólogo e adere de modo estrito ao automatismo do funcionamento da máquina. Por meio desse automatismo, tais formas no estado de sobrevivência, isto é, cindidas do contexto social e cultural em que foram produzidas inicialmente (inicialmente deve ser compreendido não no sentido de "no instante primeiro em absoluto", mas naquele de "no período histórico mais próximo em que elas apareceram em estrita relação com situações sociais e culturais"), pressupõem, da maneira mais clara, sua origem: expelem-na de si uma vez que faltam, pois ela lhes permanece solidária, os vínculos do condicionamento, mesmo que parcial, que 
presidem sua mais próxima gênese. A tensão entre mitologia e mito se faz, portanto, fortíssima e domina, não conhecida, as modalidades organizativas do fato mitológico. As conexões entre imagens mitológicas, uma vez estritas e "explicadas" por razões sociais e culturais, agora surgem autônomas em relação a tais razões e "inexplicáveis"; mas não apenas não cessam de existir, porém, fazem-se absolutamente obrigatórias, sem que sua reinterpretação à luz das novas condições sociais e culturais consiga efetivamente aliviar a tensão. Quanto mais a tensão é forte, mais ela é observável de maneira micrológica em vez de macrologicamente. A tensão, com efeito, nesse ponto de agravamento, é especialmente verdadeira no interior dos singulares núcleos constitutivos: percebendo nela, ainda que de modo obscuro, a perigosa autonomia, o autor da obra mitológica tenta rompê-la e reduzi-la a fragmentos cada vez menores: mas cada fragmento é em si completo, e a tensão, mais do que concentrada em um só ponto da obra, encontra-se, não amenizada, difundida por toda a obra em um pulverizado de núcleos constitutivos, cada um dos quais pressupondo a própria origem.

8. A situação em que se encontram as atuais investigações sobre a festa, compreendidas como reflexo das nossas atuais possibilidades (ou melhor: impossibilidades) festivas, parece explicável com base nos pressupostos de funcionamento da máquina mitológica. A máquina mitológica aparece, com efeito, como o elemento do qual deriva uma unificação qualquer entre as festas de ontem e as "festas" de hoje: ambas ocasiões espaço-temporais de funcionamento de tal máquina. Da contraposição que já indicamos entre "festa" de hoje, na qual a visão é excluída, e festas de ontem, em que a visão não era excluída, seria fácil passar à contraposição entre mito tecnicizado e mito genuíno, fazendo coincidir, sem esforço, mito genuíno e visão. Aí, todavia, essa segunda contraposição mostra, de modo particular, seus limites e os riscos de uma sua extensão indiscriminada a todos os níveis de pesquisa do fato mitológico. "Festa" de hoje e festa de ontem são ambas conexas ao funcionamento da máquina mitológica, mesmo que para a "festa" de hoje seja difícil falar de mito genuíno. A máquina mitológica sempre continua a funcionar, independente da genuinidade da substância presumida (o mito) que a faz funcionar. Ela continua a funcionar e a apontar naquilo que se diz fazê-la funcionar - o mito - uma substância genuína. Em numerosos casos é óbvio que não se trata de um mito genuíno, é óbvio que o mito é evocado e usado para especificar finalidades, portanto, tecnicizado; e todavia a máquina continua a re- 
meter a ele como a uma substância genuína e ao próprio funcionamento como ao exteriorizar de tal substância. Isso não é apenas um fenômeno de hoje: mesmo "ontem" a máquina mitológica continuou a remeter ao mito como substância genuína, mesmo nos casos em que tal substância não era, de fato, genuína.

Se agora confrontamos o funcionamento da máquina mitológica com a situação dos etnógrafos diante das festas dos diferentes, percebemos uma afinidade reveladora. A máquina mitológica, por sua própria natureza, é o que indica algo que não pode ser visto; quem usufrui de seu funcionamento se encontra vendo os traços de uma visão - o funcionamento da máquina não a visão em si - o mito. Assistindo à festa dos indígenas brasileiros, Jean de Léry viu ver, mas não viu o objeto da visão e, todavia, comoveu-se com o canto que escutava. A insistência de alguns estudiosos da mitologia, e sobretudo de Kerényi, em ligar por afinidade a mitologia à música não é distante da experiência vivida por Jean de Léry. A máquina mitológica funcionando produz uma música que é acessível com sua força de comoção também a quem não pode ter acesso à visão. Supor que as festas de ontem implicaram uma autêntica visão - além daquela "música" - significa supor que, ontem, haviam possibilidades de penetrar com o olhar através das paredes da máquina e de descobrir o que se presume que a faça funcionar: o mito. É uma suposição que hoje não podemos defender com qualquer argumento positivo, uma vez que hoje a máquina mitológica nos oferece paredes que acabam por ser, por definição, impenetráveis. Dizer que a visão é historicamente possível não tem, para nós, significado algum: essas palavras não espelham nenhum nexo gnosiológico verificável - além da abstrata concatenação sintática - em um âmbito de referimento a partir do qual nos seja permitido acesso. Podemos, porém, dizer que presumivelmente as festas de ontem não excluíam a visão. Tudo isso que sabemos das festas de ontem, por pouco que seja, não apresenta negações a priori da visão, portanto, da penetrabilidade visiva das paredes da máquina mitológica. $\mathrm{E}$, de modo mais preciso, tudo o que nós podemos extrair do estudo das tensões antigas entre mitologia e mito exclui que a visão fora impedida a priori aos participantes da festa antiga. A principal razão para suspeitar que a visão tivesse lugar consiste na percepção, nossa, de hoje, da existência de uma tensão entre mitologia e mito nas culturas "antigas". Tratase de uma percepção reflexa, que nasce da experiência da ausência de tensão entre mitologia e mito nas "festas" de hoje. Tal experiência interage com 
nosso modelo da festa antiga e carrega a realidade daquela festa com valores presumidos, acerca dos quais sabemos, acima de tudo e de maneira especial, que hoje não existem em ato. Uma vez que essa situação não é ignorada por uma parte, ao menos, dos estudiosos que trabalham nesse âmbito, seria possível falar de manipulação com má-fé dos dados relativos às festas antigas. Mas similar má-fé não é senão a componente de interesse presente em toda atividade gnosiológica: portanto, não é senão uma constante na gênese dos modelos a que recorre e em que encontra pausa temporária e criativa a experiência científica. Antropologia cultural, etnologia, ciência do mito, nasceram e subsistem como projeções em modelos gnosiológicos de carência do hoje. Essa atividade projetiva não é necessariamente confiada a personalidades individuais de operadores, e, antes, é costumeiro que múltiplas personalidades interajam na obra. O padre Lafitau, representando os costumes dos selvagens americanos, cumpria o primeiro ato de uma operação que o marquês de Sade teria integrado, traduzindo em termos de criminalidade consciente - mais do que "crainte et folie" - as práticas macabras dos selvagens. Esse exemplo é especialmente significativo uma vez que esclarece os dois instantes da interação entre a observação da ordem nos selvagens e a apologia evocativa da desordem dos civilizados. A "Festa dos Mortos" dos selvagens americanos, descrita pelo padre Lafitau ${ }^{14}$, era mais eficaz do que a "festa" cruel representada por Lucrécio no contexto da peste de Atenas, posto que aderia ao modelo formulado por seres prejudicialmente "diferentes" (ou "miseráveis" até a diferença total dos civilizados) e exprimia as modalidades de uma ordem dos "diferentes", antiga e robusta, enquanto era ocasional e precária a desordem dos "não-diferentes" atenienses. Se, ainda no tempo Sade, tivesse existido a tensão entre mitologia e mito que colocam como matriz da visão na festa antiga, as festas da revolução teriam sido o contraponto de uma efetiva experiência festiva: de Sade, de Saint-Martin, talvez do próprio Fourier. E aqui o condicional é levado ao seu valor mais drástico, de eventualidade não retórica, uma vez que a própria medida do "ontem", ao qual recorremos até agora, pode legitimamente ser levada à praxe da projeção de carências, das quais vivem as ciências humanas. A partir desse ponto de vista, o "ontem" pode objetivamente se situar muito mais próximo do hoje imediato. Mas a objetividade, nesse contexto, é esmiuçada ou multiplicada, assim como sua contra-

\footnotetext{
${ }^{14}$ LATIFAU, Joseph-François. Moeurs des sauvages amériquains, v. II. Paris: Chez Saugrain et Hocherau, 1724, p. 444.
} 
parte temporal torna-se um âmbito em que a principal variante gnosiológica é constituída pela ausência de tensão entre mitologia e mito. De fato, o que hoje prevalece é o funcionamento da máquina mitológica nos bastidores que ela prefere - das declarações acerca da sua inexistência enquanto entidade autônoma. Não há, hoje, tensão entre mitologia e mito, mas apenas, e não sempre, comoção suscitada pelos sons da máquina mitológica em funcionamento, seja ela colocada para funcionar por um mito genuíno ou não genuíno, ou, ainda, seja ela autônoma por um mito cuja existência é apenas presumida. Esses sons, essa música, são também hoje fonte de comoção; e essa música, arte não figurativa, arte "iletrada" como aparece ao humanista no Doktor Faustus de T. Mann, é hoje o único semblante verificável da mitologia a que acessamos nas nossas experiências mitológicas. Pode também acontecer que a mitologia tenha sempre sido apenas "música" e jamais imagem, visão; mas é tanto menos improvável que na festa de ontem a escuta de tal música excluísse a priori a visão, enquanto na "festa" de hoje ela não apenas exclui a priori a visão, mas com frequência cessa a si mesma, e, assim,

toda a festa adquire algo de morto, até de grotesco, como os movimentos de quem improvisadamente perde a audição e não ouve mais a música. E quem não ouve a música, não dança... ${ }^{15}$

A "festa" de hoje é com frequência algo diverso do que configuram essas palavras de Kerényi: é precisamente um continuar a dançar sem ouvir mais a música. E talvez isso já está implícito no ouvir apenas a música da máquina mitológica que funciona, excluindo a visão através das paredes da máquina. Talvez a música do funcionamento da máquina, se a visão é excluída a priori, é ela própria um silêncio durante o qual se continua a dançar.

Gostaria de dormir; mas tu deves dançar.

Esse verso de Storm ${ }^{16}$, evocando a situação de quem perdeu a dança como experiência de "ver-ser", e só escuta a música que pode ser dançada, torna-se emblemático para a "festa" do hoje. "Gostaria de dormir": é o esquecimento de consciência que pode traduzir-se na "festa" do hoje, na "festa em que somente se ouve o som da máquina mitológica, mas se exclui a priori a

\footnotetext{
${ }^{15}$ KERÉNYI, Károly. La religion antica, op. cit., p. 48.

${ }^{16}$ É o verso de Hyazinthen, citado por Thomas Mann em Tonio Kröger.
} 
eventualidade de ver. Em tal situação a música-mitologia, o som da máquina mitológica, é uma ilusão acústica que está no lugar do silêncio. A máquina mitológica só envia som enquanto a visão é possível, enquanto dura a tensão entre mitologia e mito, entre escuta e visão. Quando a visão é impossível, a tensão cai e o som torna-se vibração tão inconteste e uniforme a ponto de ser de fato silêncio. Não é "silêncio da visão", o silêncio evocado na carta de Agostinho a Mônica; é o silêncio com o qual coincide o som uniforme e constante, em espaço privado de imagens. A investigação moderna sobre a festa não pode superar o condicionamento desse som uniforme, dessa ausência de tensão entre som e visão, ao menos possível, se não factual. ${ }^{17}$

${ }^{17} \mathrm{O}$ autor continua o discurso iniciado com o presente ensaio no estudo introdutivo (Cognoscibilidade da festa) em: JESI, Furio. La festa. Antropologia culturale, etnologia, folklore. Torino: Rosenberg \& Sellier, 1977 (hoje também em JESI, Furio. Il tempo della festa. Org. Andrea Cavalletti. Roma: Nottetempo, 2013, p. 61-115). Na antologia La festa está reportada a maior parte dos documentos aqui mencionados. (Andrea Cavalletti) 